胆囊十二指腸瘻を形成した胆囊癌の 1 切除例

社会保険広島市民病院外科

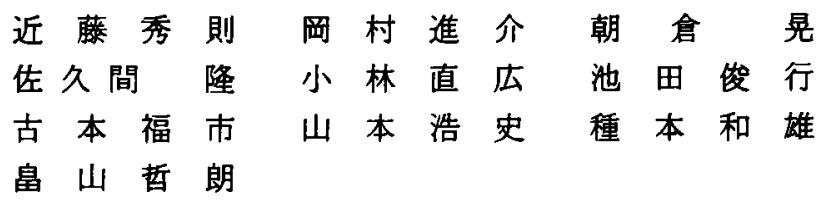

同 病理

松 浦 博 夫

\title{
A RESECTED CASE OF CARCINOMA OF THE GALLBLADDER WITH CHOLECYSTODUODENAL FISTEL
}

Hidenori KONDO, Shinsuke OKAMURA, Hikaru ASAKURA,

Takashi SAKUMA, Naohiro KOBAYASHI, Toshiyuki IKEDA,

Fukuichi FURUMOTO, Koji YAMAMOTO, Kazuo TANEMOTO

and Tetsuro HATAYAMA

Department of Surgery, Hiroshima City Hospital

Hiroo MATSUURA

Department of Pathology, Hiroshima City Hospital

最近われわれは，右季肋部腫瘤を主訴とし，胆重十二指腸掼を形成した胆重癌の 1 例 を経験したので報告する。

症例は57歳，女性. 右季肋部腫瘤を主訴として来院. 腹部には右季肋部に小肾頭大の 弾性硬の腫瘤を触知した。胃X線㭘查で十二指腸球後部より腸管外への造影剤の流出が みられ，胆重十二指晹瘦が認められた。超音波検查にて胆理上り連続する low echoの腫 瘤陰影を認め, CT 検査で肝, 腹壁および後腹膜腔に接した胆衰より連続する腫瘤陰影を

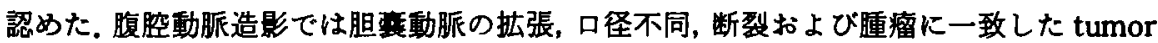
stainを認めた。 ERCPにて十二指腸に 2 カ所の瘦孔開口部を認め, その周辺を生検し Group V と判明した。注腸検査では横行結腸に腫瘤による壁外性の圧排像を認めた。

以上より，胆弶十二指腸瘦を形成した胆重癌の術前診断にて手術を施行した，腫瘍は

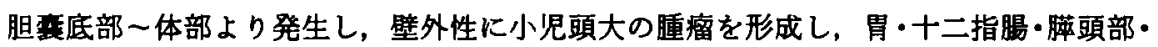
横行結腸・横行結腸間膜に浸潤していたが、肝床部・総胆管・門脈への浸潤はなく，胆

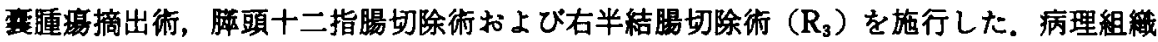
学的診断は胆栾原発の分化型乳頭状腺癌であり, 胆道癌取扱い規約によると, stage IV $\left(\mathrm{N}_{0} \mathrm{~S}_{3} \quad \mathrm{~B}_{0} \quad \mathrm{Hinf}_{0} \mathrm{H}_{0} \mathrm{P}_{0}, \mathrm{n}_{3} \mathrm{~S}_{3} \mathrm{~b}_{0}\right)$ で相対治复切除であった。術後 1 年目の現在生存中で ある.

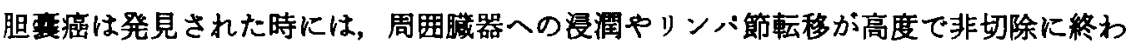
ることが多いが，他臓器浸潤がある場合でも，積極的な合併切除により延命が期待でき るすのと考える。

索引用語：胆考癌, 胆衰十二指腸瘦 
はじめに

胆害癌は診断が可能になった時期には、リンバ節転 䔟中周囲藏器への浸潤のため切除不能とされることが 多く, 消化器悪性腫瘍のうちでも最も予後不良なるの の1つである. 最近われわれは，胆衰十二指腸㾇を形 成した進行胆堡癌に対し, 胆衰腫瘍摘出術, 满頭十二 指腸切除術および右半結腸切除術により切除し得た 1 例を経験したので報告する。

\section{症例}

患者：57歳，女性

主訴：右季肋部腫瘤

既往歴, 家族歴：特記すべきるのなし

現病歴：生来健康で著患を知らなかったか，1982年 10月20日頃より右季肋部の無痛性腫瘤に気づき近医を 受診, 10月29日当科に紹介され諸検査施行後, 11 月 22 日胆婁腫場の疑いで入院した。な経過を通じ消化器 症状は全く認められなかった。

入院時現症：体格・栄養中等度, 体温 $36.6^{\circ} \mathrm{C}$, 血圧 $146 / 86 \mathrm{mmHg}$, 脈拍 $72 /$ 分で整. 眼瞼結膜に軽度の䝯血 を認める以外は頭・頝・胸部に理学的所見の異常は認 められなかった，腹部には右季助部に小児頭大の腫瘤 を触知し, 畽瘤の硬さは弾性硬で, 境界は比較的明瞭, 圧痛はなく，可動性もなかった，腹水および腹壁静脈 怒張は認めなかった。ダグラス蒚に異常所見はなく， 表在リンバ節の畽脹む認められなかった。

入院時検查成績：便潜血陽性，貧血，白血球增多， 血沈の充進, CRP $(3+), A L P ・ L A P ・ \gamma-G T P$ の 昇, CEA の著明な上昇, IAP の軽度上昇等が認められ た（表 1 ). 胸部X線像，心電図正常であった。

胃十二指腸透視所見：胃前庭部大弯に圧排像がみら れるとともに，C-loopの拡大が認められた，十二指腸 球後部および下行脚より造影剂の腸管外への流出がみ られ，腹臥位にて胆衰と十二指腸球後部との間の内瘦 （胆售十二指腸瘦）が明らかになった。胆表内には 2 個 の結石像が認められた（図 1).

腹部超音波所見：胆震内に音響陰影を伴った結石像 および胆䇎より連続する low echoの腫瘤陰影を認め た。腫瘤陰影の辺縁招よび内部ェコーは不整であるが, 境界は明瞭であり，肝との境界も比較的鮮明であった (図 2 ).

腹部 CT 所見：右上腹部に肝, 腹壁および後腹膜腔 に接した充実性の隀瘤陰影が認められ, 胆衰より連続 しており胆豪原発の腫瘍と考兄られた。腫瘤内部には, 一部 low density area および含気性を有する部分（胆
表 1 入院時検査成繶

\begin{tabular}{|c|c|c|c|}
\hline \multicolumn{4}{|l|}{ 血液 } \\
\hline RBC & $352 \times 10^{4} / \mathrm{mm}^{3}$ & T.P & $7.0 \mathrm{~g} / \mathrm{dl}$ \\
\hline $\mathrm{Hb}$ & $9.7 \mathrm{~g} / \mathrm{dl}$ & Alb & $3.6 \mathrm{~g} / \mathrm{dl}$ \\
\hline $\mathrm{Ht}$ & $29.4 \%$ & ESR 1 時間 & $70 \mathrm{~mm}$ \\
\hline WBC & $26,900 / \mathrm{mm}^{3}$ & \multicolumn{2}{|c|}{2 時間 $112 \mathrm{~mm}$} \\
\hline Plt & $38 \times 10^{4} / \mathrm{mm}^{3}$ & \multicolumn{2}{|c|}{$141.4 \mathrm{mEq} / l$} \\
\hline T. bil & $0.5 \mathrm{mg} / \mathrm{dl}$ & $\mathbf{K}$ & $4.5 \mathrm{mEg} / l$ \\
\hline GOT & $13 \mathrm{mIu} / \mathrm{ml}$ & $\mathrm{Cl}$ & $99.2 \mathrm{mEq} / l$ \\
\hline GPT & $18 \mathrm{mIu} / \mathrm{ml}$ & BUN & $17 \mathrm{mg} / \mathrm{dl}$ \\
\hline LDH & $250 \mathrm{mIu} / \mathrm{ml}$ & FBS & $119 \mathrm{mg} / \mathrm{dl}$ \\
\hline ALP & $525 \mathrm{mlu} / \mathrm{ml}$ & CRP & $(3+)$ \\
\hline LAP & $95 \mathrm{mlu} / \mathrm{ml}$ & AFP & $5.0 \mathrm{ng} / \mathrm{ml}$ \\
\hline$\gamma$-GTP & $127 \mathrm{mlu} / \mathrm{ml}$ & CEA & $23.5 \mathrm{ng} / \mathrm{ml}$ \\
\hline TTT & 0.8単位 & \multirow[t]{2}{*}{ IAP } & \multirow[t]{2}{*}{$655 \mu \mathrm{g} / \mathrm{ml}$} \\
\hline ZTT & 5.6 単位 & & \\
\hline \multicolumn{2}{|l|}{ 尿 } & \multicolumn{2}{|l|}{ 便 } \\
\hline Protein & $(-)$ & \multirow{3}{*}{$\begin{array}{l}\text { 潜血 } \\
\text { 寄生虫 }\end{array}$} & $(+)$ \\
\hline Sugar & $(-)$ & & $(-)$ \\
\hline Urobilin & gen $\mathrm{N}$ & & \\
\hline
\end{tabular}

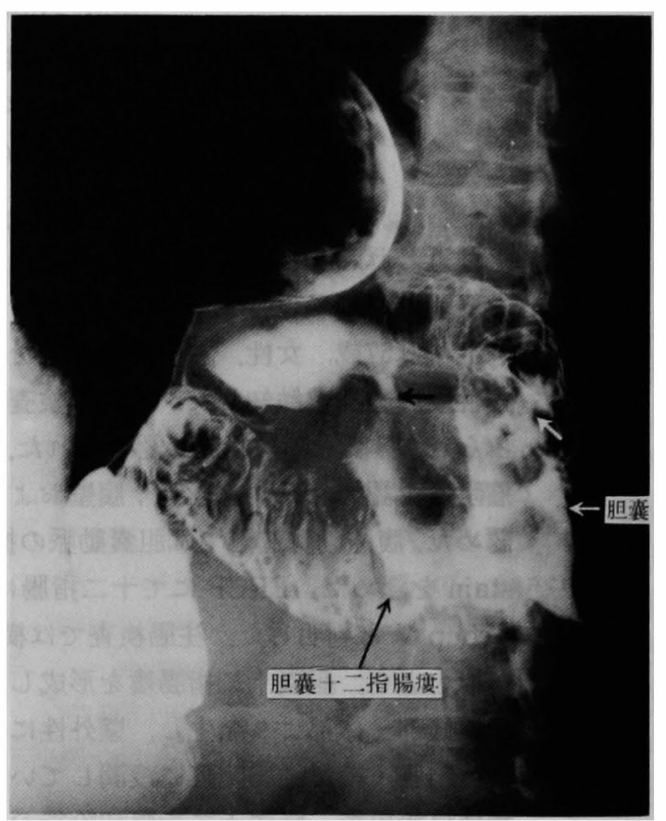

园 1 周十二指渴透視（腹卧位像）

十二指腸球後部および下行脚より造影剂の腸管外 への流出（矢印）を認めるととるに胆衰十二指䭪瘄 が認められる，胆西内には 2 個の結石像を認める.

衰十二指腸㾇に相当）が認められた（図 3 ）。

腹腔勤脈造影所見：動脈相では胆蕒動脈の执張㧍よ び一次分枝に口径不同，断裂を認め，周囲血管への軽 度の圧排を認めたが，周囲血管の encasement は認め 


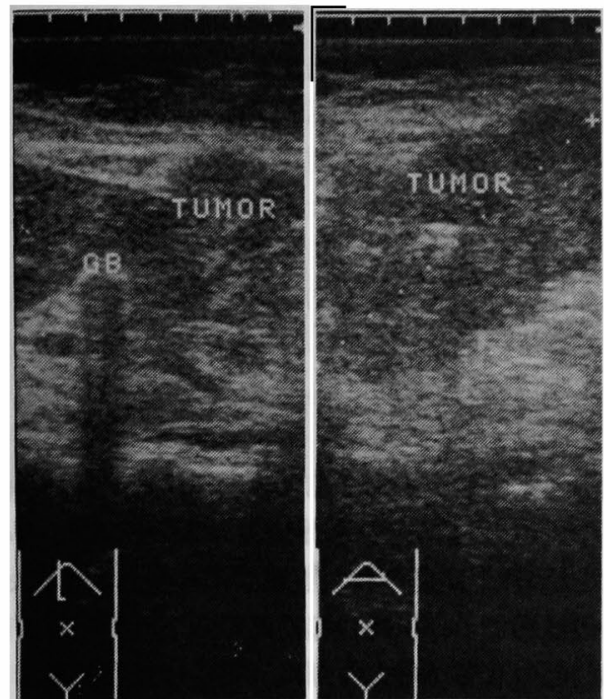

図 2 腹部 US 像

左：右季肋部縦断像, 右：右季肋部 心窝部横断

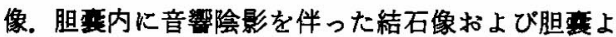
り連続する low echoの尰瘤陰影を認める。

られなかった。 また胃十二指腸動脈分枝より腫瘤へ流 入する血管を認めた。静脈相では腫瘤に一致した tumor stain が認められた（図 4 ）。

ERCP 所見：総胆管, 主腪管に異常所見は認められ なかった. 十二指腸球後部前壁および Vater 乳頭部前 壁奇りの 2 カ所に瘦孔の開口部を認め, 後者の瘻孔開
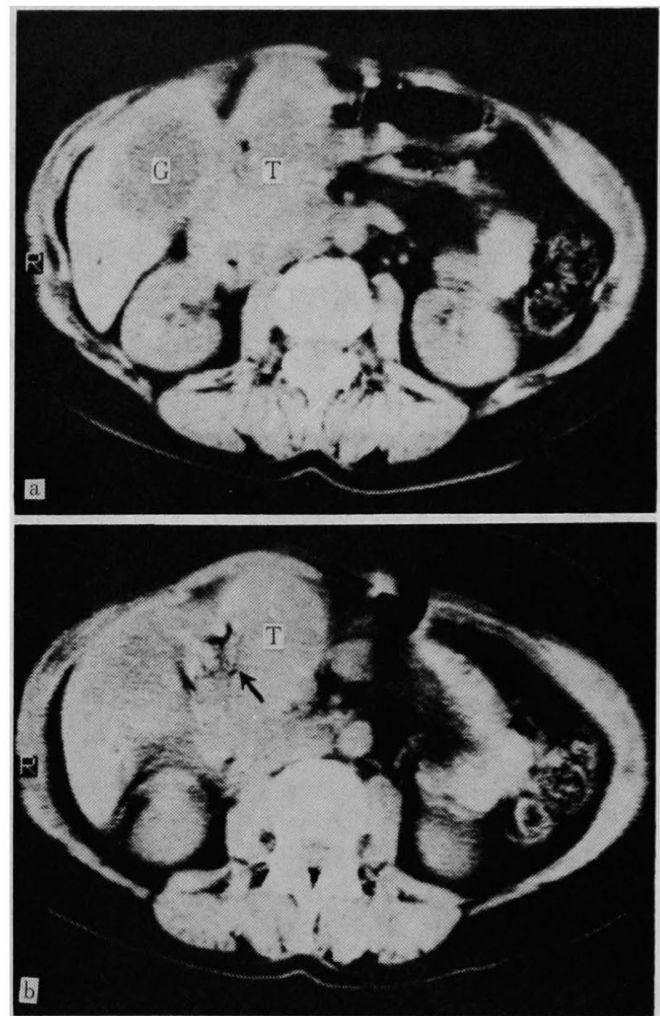

図 3 腹部 CT 像

$\mathbf{a}$ ：胆萃 $(\mathrm{G})$ より連続する充実性の腫瘤陰影 $(\mathrm{T})$ を認める. b：腫瘤内部には一部 low density area 怙よび含気性を有する部分（失印）を認める。

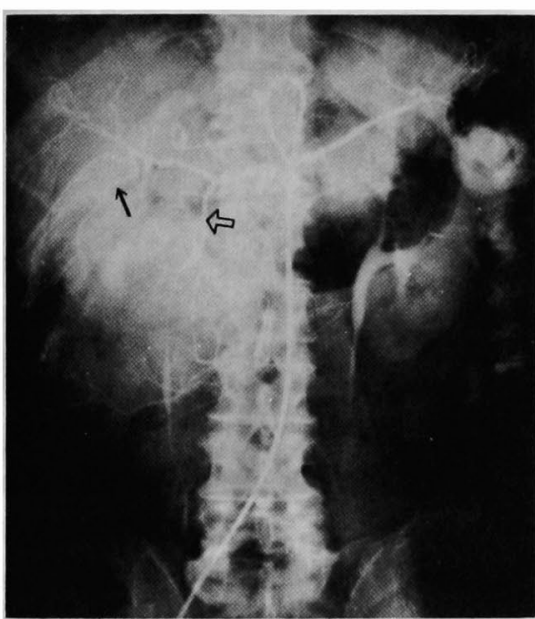

動脈相

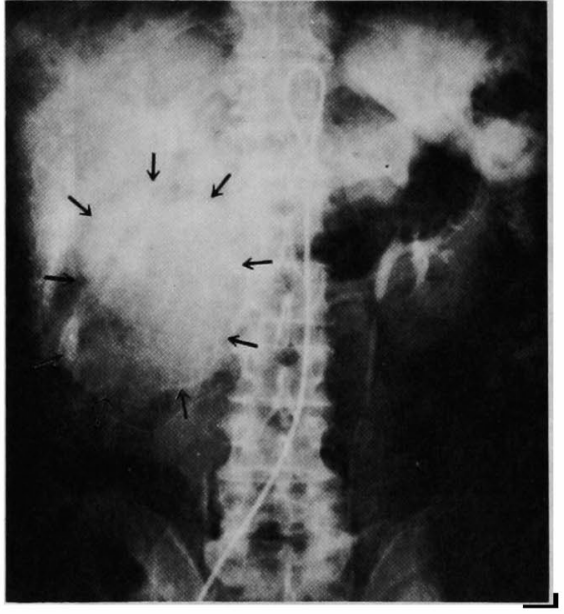

静脈相

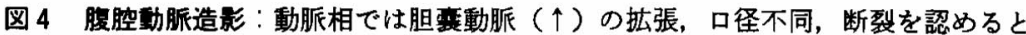
ともに，胃十二指腸動脈（へ）の分枝より腫瘤へ流入する血管を認める，静脈相で は腫瘤に一致した tumor stain（†）を認める。 
口部（図 5）周辺を生検し Group V と判明した。 注腸透視所見：横行結腸に腫瘤による上からの圧排 像を認めた（図6）。

以上の諸検查より，胆嚄原発の悪性腫瘍が十二指腸 に漫潤し胆变十二指腸瘦を形成し, 腫瘍の肝床部・胃・ 横行結腸への浸潤の可能性もあり得るとの術前診断に て1982年12月 7 日手術を施行した。

手術時所見：上腹部正中切開にて開腹するに, 腹水,

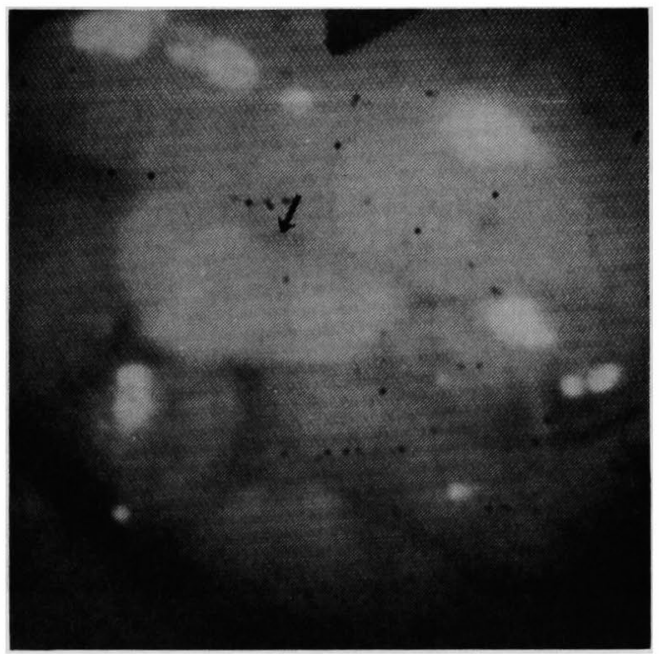

図 5 十二指腸瘦孔開口部の内視鏡像 瘦孔開口部（矢印）の周辺に周堤状の隆起を認め る. 表面は浮腫性で易出血性である.

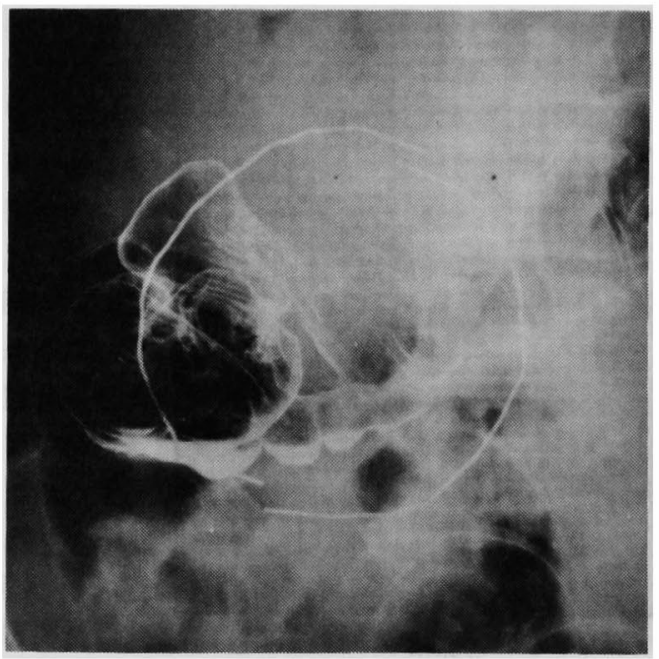

图 6 注得透視像

横行結腸に壁外性の圧排像を認める。マーカーは 体表面における腫瘤の境界を示す。
腹膜播種は認められず，肝に著変を認めなかった。腫 場は胆言底部〜体部より発生し壁外性に小児頭大の董 瘤を形成し，胃・十二指腸・荤頭部・横行結腸・横行 結腸間膜に浸潤し一塊の腫瘤となっていた，肝床部・ 総胆管・門脈への漫潤はなく，リンパ節も転移を思わ せるものは認められず, 胆主腫湯摘出術, 䐙頭十二指 腸切除術および右半結腸切除術を施行した。リンパ節 郭清は胆道癌取扱い規約1)に基づき $\mathrm{R}_{3}$ を行い, 羘頭十 二指腸切除後の再建は Billroth I 法式（今永法）を施 行した。

摘出橙本所見：胆咅底部〜体部にかけては，壁内お よび壁外性の発育を来した $10.0 \times 9.0 \times 7.4 \mathrm{~cm}$ 大の尰

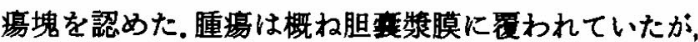
その辺縁部で十二指腸の起始部から下行脚, 䜕頭部, 胃幽門部の後壁から大弯側に，更には横行結腸および 横行結腸間膜に漫潤性の増殖を来していた。古指腸

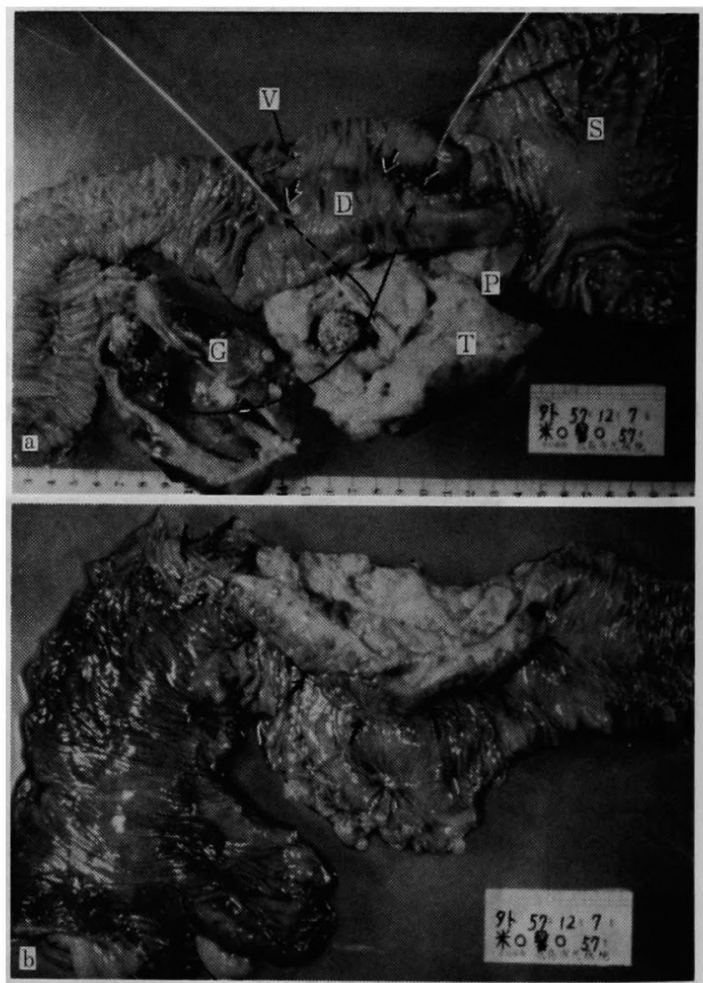

图 7 揞出标本写兵

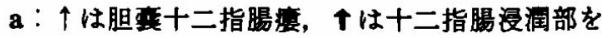
示す、ソンデは十二指腸漫洞部および総胆管に挿入 している， S : 胃，D：十二指腸， V：Vater 乳頭， $G$ ：胆麦， $T$ ：胆莫底部〜体部より発生した壁外生 腫瘤, $\mathrm{P}$ : 苹頭部, b：矢印は横行結腸浸润部を示 す。 


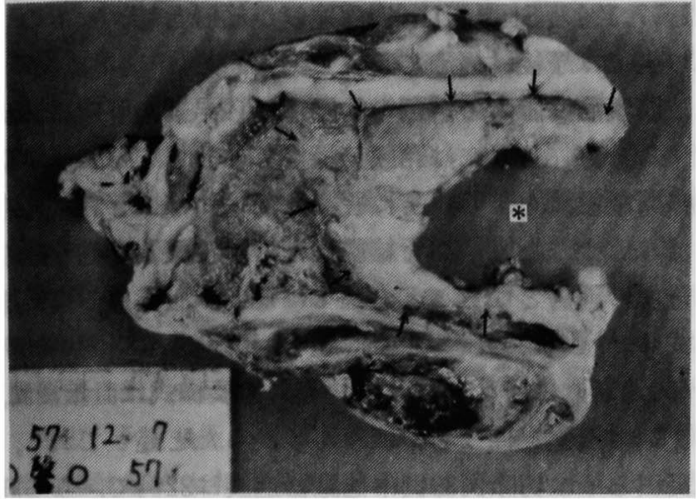

图 8 摛出胆要固定栖本写真(粘膜面)

矢印は腫瘍組織部分，*は胆垔十二指腸瘦の入口 部を示す。

下行脚の粘膜面には最大径 $3.2 \mathrm{~cm}$ 大, $3.0 \mathrm{~cm}$ 大の 2 個 の潰瘍形成を認めた。腫瘍は灰白色，弾性軟で中心部 は広筙な壊死に陥っていたが，この壊死部分之胆要底 部の内腔および十二指腸の潰場部分とは相互に交通し ていた，胆言内に 2 個，壁外性腫瘤の中に 1 個（すべ てコ系石)の結石を認めた（図 7 ）。図8 は摘出胆震の 固定標本（粘膜面）であり，胆衰底部～体部の壁内に 漫润増殖する $7.0 \times 5.0 \mathrm{~cm}$ 大の比較的境界明瞭な腫湯 組織を認めた。

病理組籍学的所見：嗹場は分化型乳頭状腺癌であっ た（图9-a），胆谼では腫湯部分を除いて急性および慢 性炎症像が著明で，壁内にしばしば RokitanskyAschoff 洞の形成をみた他，腫場部分周囲の粘膜に初 期漫潤像を示す分化型腺癌組織を認めた（図9-b). 他 賊器組織には原発尰瘍を窺わせる所見は認めず，浸潤 像仕胃前庭部大弯，十二指腸，羘頭部，横行結腸扰よ び横行結腸間膜に認められ，摘出された 6 個のリンバ 節のらち，脇頭前部リンパ節に 1 個転移がみられた。 摘出標本の各喴器組織の断端には腫場の浸潤は認めら 概加た。

以上の肉眼所見ならびに組織学的所見から，壁外性 発育を呈した胆重底部原発の腺癌と診断した，胆道癌 取扱い規約》によると, $\mathrm{N}_{0} \mathrm{~S}_{3} \mathrm{~B}_{0}$ Hinf $_{0} \mathrm{H}_{0} \mathrm{P}_{0}$ Stage IV， $\mathrm{n}_{3} \mathrm{~s}_{3} \mathrm{~b}_{0}$ stage IV で相対治痽切除であった。

術後経過：術後一時血清肝炎を併発したが，術後56 日目に軽快退院し，術後 1 年目の現在生存中である。 術前23.5ng $/ \mathrm{ml}$ と異常高値を示した血清 CEA 值は, 術後 1 力月目には $1.7 \mathrm{ng} / \mathrm{ml}$ と正常域に低下し, 現在 follow up 中である.

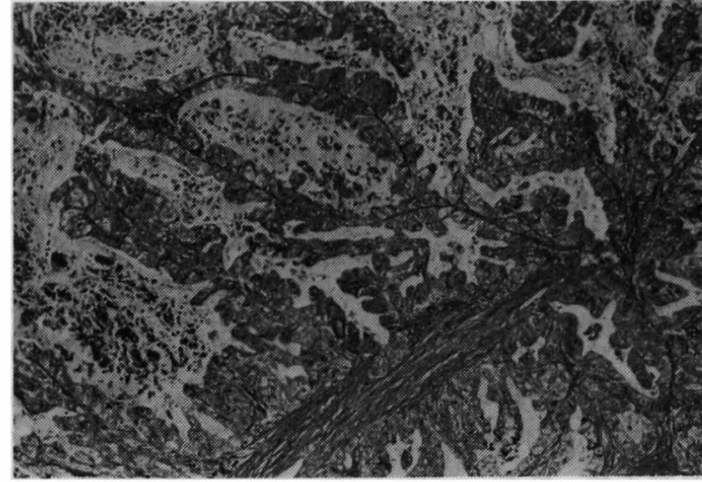

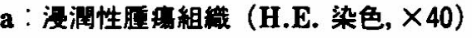
分化型乳頭状腺癌の像を認める。

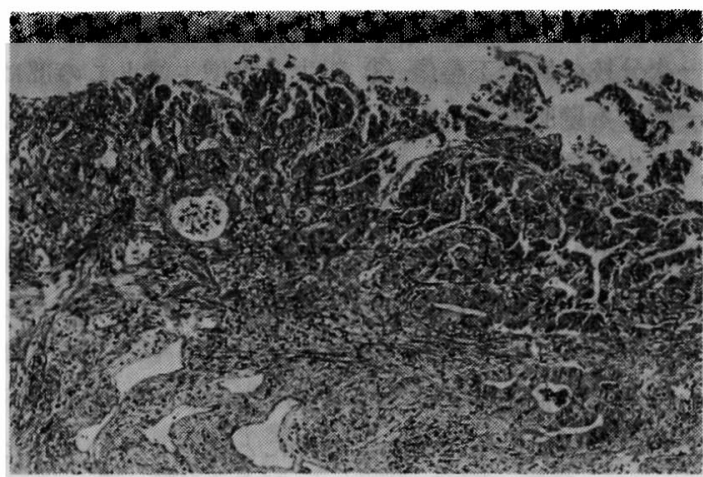

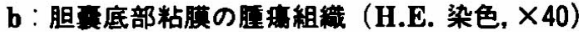
胆重粘膜上皮内に分化型腺癌の像を䜅める。

图 9 病理組繒像

考察

最近の胆道系に対する補助検査法の進歩により, 早 期胆震癌の報告も散見されるようになったものの早期 には癌としての特有な症状がないため, 進行胆爰癌と して発見される場合が多いのが現状である。

胆栾癌の診断として最近では，USおよびCT の有

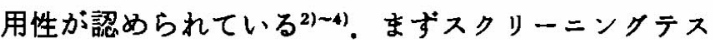
トとしてはUSを, 次いでCTを行い, 疑わしいものに は血管造影を行らべきものと考える. 胆衰癌のェュー バターンについては, Yeh"), 安田6), 渡辺"の報告があ るが, 本症例はYehの分類で I 型(充実型), 安田の分 類でIV型 (全体腫瘤型)，渡辺の分類でIV型 (びまん性 畽瘤型)に相当するすのと思われる.土屋ら ${ }^{8 /}$ は胆毫癌 36例の超音波所見を安田の分類6)に基づき検討し，本 症例に相当するIV型は10例ですべて進行癌であり，5 ち 1 例のみが切除例（非治瘜）であったと報告してい る. 渡辺”は胆衰癌41例のエコーパターンを分析し，本 
应例に相当するIN型は15例で，5ち5 例が切除例で治 疮切除は 1 例(6.7\%)であったと報告している.ェコー パターンとして，ポリーブ型あるいは限局畽瘤型を示 寸場合は早期例 多く切除例が多いのに対し，壁不整 肥厚型，全体腫瘤型特に後者では進行例が多く，非切 除に終わる場合が多いと考えられている8．

胆变癌の確定診断としては，腹腔動脈造影が有用と されている. 山内ら"9胆衰動脈の扗張とその支配領 域の拡大，胆亯動脈分枝の中断，濃染像，異常な屈曲 蛇行像，広狭不整像などをあげ，吉田ら 管腔不整，断裂，pathologic vesselsの增生および tumor stainをあげている.今野ら"11は治䈍切除可能な

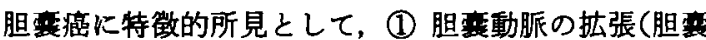
動脈内径は右肝動脈内径の $1 / 3 \sim 1 / 2$ ), (2) 胆衰動脈の 一次分枝の管径不整像，(3) 新生血管增生像とこの部に 一致する壁肥厚浱染を伴 5 卯殻状陰影または $15 \mathrm{~cm}^{2}$ 以 下の小範囲にみられる斑状港染像をあげている。柏井 ら ${ }^{12)}$ は胆竞癌の進展様式と血管造影所見の検討より， 周囲䑏器人の進展につれ肝内動脈枝, 固有肝動脈, 胃 十二指腸動脈の王排，さらに狭窄，閉塞がみられると し，所見がこれら周囲血管の王排を主とするものでは 一部切除可能なるのるみられるが, encasementを示 すすのでは全例切除不能であったと報告している，と ころで本症例では，胆重動脈の払張，口狭不整，断裂， tumor stainがみられ，十二指腸および朠頭部へ浸潤 していたため，胃十二指腸動脈分枝より腫㑥へ流入す る血管が認められた。 また周囲血管の軽度の圧排像は 認めたが, encasementは認めなかった。胆素癌におけ る血管造影で所見が胆衰に限局し，周囲血管の encasement が認められない症例に対しては，積極的な 外科的切除の態度で望むへきすのと考える。

胆衰癌の外科治療成績については，いまだ満足す べきのではない.吉川ら 術総数 126 例の5ち切除例は64例，切除率51\%，治䧗切 除は34例, 治疾切除率27\%と低く，切除例64例の Stage は Stage I 14\%, Stage II 19\%, Stage III 17\%, Stage IV 50\%で Stage III, IV 合わせて67\%もあり，多くは 外科的に限界的な進行癌例である。佐藤ら'4191976年 の全国集計によると，胆衰癌 1,381 例中治瘦切除は217 例(15.7\%)であり，横山ら ${ }^{15)} 1979$ 年の全国集計では, 2,569 例中治瘦切除は 497 例（19.3\%）と若干の上昇は みられるむのの，極めて低率と言わざるをえない， た胆烡癌根治切除症例の Stage 別 5 年生存率は Stage I $90.0 \%$, Stage II $58.9 \%$, Stage III 16.7\%, Stage
IV 7.1\%と Stage III（癌深達度が筋層を越えたもの） 以上では予後は極めて不良である15)。

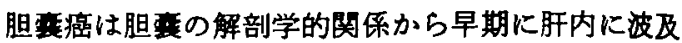
する一方，胆堡には粘膜筋板が欠如しているため早期 に脂莫浸潤を来し，特に胆衰底部一体部に存在する癌 では，十二指腸，横行結腸などの隣接搭器を巻き込み 一塊の腫場となることも稀ではない，胆变癌の進展様 式について，持永 ${ }^{16)}$ は胆垂癌手術総数85例 中55例 （59.1\%）に肝への波及を認め，進展様式は直接漫潤。 次いで浸潤を伴ら右葉転移が多かったと述べており， 高田 ${ }^{17}$ は切除例39例中他藏器進展は22例で，5ち肝 浸潤17例 (77.3\%)，肝転移 2 例 $(9.1 \%)$ ，胆管漫湢18 例 $(81.8 \%)$ ，十二指腸漫潤 9 例 (40.9\%)，横行結腸 浸潤 2 例 $(9.1 \%)$, 胃浸潤 1 例 $(4.5 \%)$ ，椫漫潤 1 例 (4.5\%)，リンバ節転移22例（100\%）と報告している。 Fahim ら ${ }^{18)}$ は胆要癌手術症例151例の進展様式につい てリンパ節転移 $25 \%$ ，脈管進展 $13.1 \%$ ，胆重・総胆管 周囲の神経浸潤 $24 \%$ ，胆管進展 $4.0 \%$ ，肝転移・浸潤 $34 \%$ であったと述へてている，本症例は胆重底部～体部より 発生し，右季肋部腫瘤を形成した進行胆重癌でありな がら，肝床部への浸潤，肝転移は認められず，腹側へ の漫潤傾向が強かったのは進展様式として興味深い。

進行胆蒉癌の手術術式については，また一定の見解 はない，筋層以上に進展した胆表癌に対する払大胆摘 術もその予後は悪〈10115119), Stage III 以上の症(例に対 しては，より根治的な手術術式が行われている.持永 ${ }^{16)}$ は前下，中下領域の肝区域切除十羘頭十二指腸切除を, 宮崎 ${ }^{201}$ は後腹膜郭清を伴 5 選択的肝区域切除（右後 区，右前下区，中下区切除）十椫頭十二指腸切除を，高 崎 $5^{211}$ は桩大肝右葉切除 + 䐙頭十二指腸切除を, 横山 $5^{22)}$ は抾大肝右葉切除十第 1 群, 第 2 群 リン八節郭清,

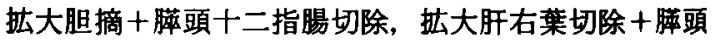
十二指腸切除のいずれかの術式に術中照射などの制癌 剂付加療法を加えるとしている。しかし，払大肝右葉

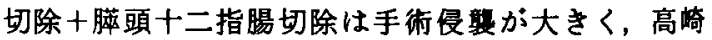
$5^{211}$ は 5 例中 3 例を，杉浦ら ${ }^{23}$ は 8 例中 5 例を術死で 失っており，かつ予後の改善るそれ和みられて拈ら ず，この術式は時期早尚とも考えられている ${ }^{29}$. 宮崎 $ら^{24)}$ は，胆言癌のらち限局型で腹側への漫潤が先行し て胆度への浸潤が軽度なるのについては, Glenn ら 25)の提唱する胆谼床より約 $1 〜 2 \mathrm{~cm}$ 離れて肝の一部 合併切除を行ういわゆる肝契状切除術と所属リンハ節 の郭清が肝要であると述べ，肝浸潤・胆管浸閏のない 胆囊癌に対しては，Glennの手術を標準術式としてい 
る.ところで本症例は，胃・十二指腸・䐙頭部・横行 結腸と多くの周囲葴器に浸潤する進行胆筃癌であった が, 術中の肉眼所見で明らかに肝床部への浸潤はなく， 腹側への進展様式を重視し, 胆辑腫痬摘出術, 苹頭十 二指腸切除術および右半結腸切除術の合併切除と領域 リンパ節の郭清を行い, 治瘦切除し得た症例である.

胆癌による内胆汁瘦形成については，その発生は 稀であり，報告す少ない20127). また内胆汁瘦を形成した 䏣䔄癌は進行例が多く非切除に終わる場合がほとんど

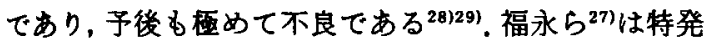
性内胆汁瘖の本邦報告例183例を原因別に分類し，胆石 症・胆亨炎によるすのは167例（91.3\%）で大部分を占 め, 十二指腸潰瘍 8 例 $(4.4 \%)$, 胆菨癌 8 例 $(4.4 \%)$ であり，胆衰癌の 8 例中 2 例が胆軎十二指腸瘦であっ たと報告している.吉田ら ているが，そのうち 3 例 (27.3\%) が胆变癌によるも ので，それぞれ術後55日，58日，2 日で死亡しており， その予後は不良である. 代田ら ${ }^{29)}$ の内胆汁瘦20例の報 告では，胆就によるすのは 2 例 $(10.0 \%)$ であり， いずれも胆素十二指腸瘦でうち1例は肝および総胆管 への浸潤が著しく切除不能であったと述べている.内 掼の発生機序としては，胆石・胆咅炎の場合は，胆表・ 胆道の炎症性変化 $\rightarrow$ 癁着 $\rightarrow$ 主として結石による王迫壊 死 $\rightarrow$ 穿通 $\rightarrow$ 瘦形成が考えられている30131). 胆考癌の 場合には，癌の浸潤・疾着 $\rightarrow$ 癌組織の壊死・崩壊 $\rightarrow$ 穿

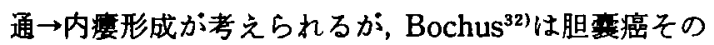
るのが浸潤し，穿通，瘦孔形成にいたるといら一次的 な原因によるすのではなく，むしろ癌に先発する胆石， 慢性胆蓄炎が瘦孔形成の主因であると述べている ${ }^{30)}$. 本症例は基盤に胆石症による慢性胆资炎があり，胆竞 底部と十二指腸との間に瘜着が存在し，この瘵着部付 近の胆要より癌が発生し腹側への畽瘤形成性の進展を 示し,さらに癌組織の壊死・穿通により胆蒜十二指腸 㿉は形成されたすのと推察される。

\section{結語}

57歳の女性で，右季肋部腫瘤を主訴とし，胆蒢十二 指腸瘦を形成した胆变癌の 1 切除例を释験したので， 若干の文献的考察を加えて報告した。本症例のように， 腹膜転移・肝転移がなく腹側への浸潤形式で，胃・十 二指腸・䐙・横行結腸等の他藏器浸潤がある場合でも, 領域リンパ節の郭清と適切かつ積極的な合併切除によ ク，延命は十分期待できるのと考える.

なお本論文の要旨は第45回日本臨床外科医学会総会 （1983年11月，広島）において発表した。

\section{文献}

1) 日本胆道外科研究会編：外科胆道癌取扱い規約. 金原出版，東京，1981。

2）川尻 孝, 吉岡正智, 三樹勝他：胆莫癌の診断 一特に超音波診断を中心として一，日消外会誌， $15: 1591-1596,1982$.

3）安川章裕, 蜂須賀喜多男, 山口晃弘他：USおよび CTによる胆可癌の診断一切除標本との比較検討 一，日消外会誌，15：1597-1601，1982.

4）渡辺羕二，竜 崇正，菊地俊之他：胆英癌の診断と 治㬌一各種検查所見よりみた手術々式の娭討一, 日消外会誌, $15 ： 1608-1613$ ， 1982.

5) Yeh, H.C.: Ultrasonography and computed tomography of carcinoma of the gallbladder. Radiology, 133 : 167-173, 1979.

6) Yasuda, Y., Kashii, A., Kasahara, K. and Itoh, K. : The Diagnosis of Gallbladder Carcinoma with Ultrasound Image. p. 135, ed., Levi, S., Ultrasound and Cancer, International Congress Series 587, Excerpta Medica, Amsterdam, 1982.

7）渡辺栄二：超音波断展法による胆素癌診断に関す る臨床的研究一とくに早期診断能について一，日 消外会誌, $16 ： 1684-1693,1983$.

8）土屋幸治，大藤正雄：胆道疾患における超音波猃 断, 消化器外科, $5: 1734-1759,1982$.

9）山内英生, 中島康之, 小山研二他：胆の5癌の診断 と治療一とくに血管撮影からみた胆のう炎との鑑 別を中心として一，日消外会誌，9：163-169, 1976.

10）吉田晃治，笠原卓，仲䲴孝治他：胆蒵癌の臨床 像, 外科, $40: 448-455,1978$.

11）今野俊光，持永瑞恵，上村邦紀他：血管造影による 胆垔癌の診断, とくに切除可能性の診断, 日消外会 誌, $15: 1602-1607,1982$.

12）柏井昭良，笠原小五郎，原 辟一他：胆栾庭の血管 造影法による診断，日消外会誌，12：443-450, 1979.

13）吉川達也，羽生富士夫，中村光司他：胆莫痁払大手 術の意義，日臨外会誌，44:816-819，1983.

14）在藤寿雄：胆癌の治療をめぐる2,3の問題点, 外 科, $38: 373-380,1976$.

15）横山育三，田代征記，今野俊光他：本邦における胆

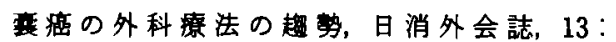
1362-1368, 1980.

16）持永瑞恵：胆表癌の進展様式と治㞠方針に関する 研究，日消外会誌，16：1334-1344，1983. 
17）高田忠敬，内山勝弘，安田秀言他：胆变癌一肉眼 型, 癌進展と予後一，胆と满，2：813-820, 1981.

18) Fahim, R.B., McDonald, J.R., Richards, J.C. and Ferris, D.O. : Carcinoma of the gallbladder. A study of its modes of spread. Ann. Surg., 156 : $114-124,1962$.

19）传藤寿雄, 小山研二：胆竞癌に対する払大㮛治手 術一いわゆる払大胆摘術の遠隔成䋩の反省から 一, 消化器外科, 5:191-197, 1982.

20）宮崎逸夫，永川宅和，磯部次正：胆素癌根治手術 （選択的肝区域切除術兼椫頭十二指腸切除術），消 化器外科, 4:486-496, 1981.

21）高崎 健, 小林誠一郎, 武落晴臣他：払大右葉切除 兼脑頭十二指腸切除により切除し得た胆癌 5 例 の検討, 胆と椫, $1: 923-932 ， 1980$.

22）横山育三, 持永瑞恵, 田代征記他：胆衰癌の臨床, 胆と䐙， $2: 179-191 ， 1981$.

23）杉浦芳章, 島 伸吾, 米川甫他：胆变癌払大根治 術と合併症対策, 日消外会誌，15：1631-1635, 1982.

24）宮崎逸夫，永川宅和：胆道癌取扱い规䄪之胆要癌 の予後, 消化器外科, 5:207-212, 1981 .
25) Glenn, F. and Hays, D.M. : Radical surgery in the treatment of malignant tumors of the extrahepatic biliary tract. Surg. Gynecol. Obstet., 99 : $529-541,1954$.

26）山口 晋, 出月康夫, 窪田偻他：特発性内胆斗瘄 の診断と治療, 手術, $33: 343-347,1979$.

27）福永裕充, 青木洋三, 勝見正治他：特発性内胆计度 一自検例23例を含めた本邦症例の集計と文献的考 察一，日臨外会誌，43:173-182，1983.

28）吉田晃治, 松永 章, 村石信男他：特発性内胆计 度，外科，41:40-48，1979.

29）代田明郎, 山田静雄, 田代真一他：内胆汧度の診断 と治療，消化器外科，6：397-407，1983。

30）古沢俤二, 久次武晴, 甲斐祥一他: 特発性内胆计 度, 外科診療, $15: 330-336,1973$.

31) Safaie-Shirazi, S., Zike, W.L. and Printen, K.J.: Spontaneous enterobiliary fistulas. Surg. Gynecol. Obstet., $137: 769-772,1973$.

32) Bochus, H.L. : Gastroenterology, Vol. 3, Saunders, Philadelphia \& London, 2nd Ed., p. 852 , 1966. 